\title{
WHAT IS THE BEST DISTAL LEVEL OF ARTHRODESIS IN LUMBAR FUSION IN PATIENTS WITH ADOLESCENT IDIOPATHIC SCOLIOSIS: L3 OR L4?
}

\author{
QUAL O MELHOR NÍVEL DISTAL DE ATRODESE NA FUSÃO LOMBAR DO PACIENTE COM \\ ESCOLIOSE IDIOPÁTICA DO ADOLESCENTE: L3 OU L4?
}

\section{¿CUAL ES EL MEJOR NIVEL DISTAL DE ARTRODESIS EN LA FUSIÓN LUMBAR EN PACIENTES CON ESCOLIOSIS IDIOPÁTICA DEL ADOLESCENTE: L3 O L4?}

\author{
Murilo Tavares Daher, ${ }^{1,2}$ Nilo Carrijo Melo, ${ }^{1}$ Vinício Nunes Nascimento, ${ }^{1}$ Pedro Felisbino Jr, ${ }^{1}$ Brenda Cristina Ribeiro Araújo, ${ }^{1}$ Sérgio Daher, ${ }^{1}$ \\ Marcelo Fouad Rabahl ${ }^{2}$ \\ 1. Centro de Reabilitação e Readaptação Dr. Henrique Santillo, Spine Group - CRER, Goiânia, GO, Brazil. \\ 2. Universidade Federal de Goiás, Faculdade de Medicina, Department of Orthopedics and Traumatology - DOT/FM/UFG, Goiânia, GO, Brazil.
}

\begin{abstract}
Objective: To evaluate coronal alignment in patients with idiopathic adolescent scoliosis with structured lumbar curves submitted to surgical treatment by comparing coronal alignment in the group fusion up to L3 and the group fusion up to L4. Methods: Retrospective cohort study. We evaluated patients submitted to surgical treatment with arthrodesis of the lumbar curve with high density of screws with at least 6 months of follow-up. Radiographically, coronal alignment, shoulder height and functional outcome were analyzed through SRS30 questionnaire. Results: A total of 25 patients were analyzed, of which 23 were female and 2 were male, with a mean age of 15.2 years (12 to 29 years) at the time of surgery. The patients were divided into two groups. Group A, n = 15: Distal level of fusion in L3 and Group B, $n=10$ : distal level of fusion in L4. There was no statistically significant difference between Groups A and B when compared to coronal alignment (balanced vs. unbalanced). However, when compared with the coronal alignment (CA) values, lower values of CA were observed in Group A, with statistical significance. No difference was observed between Groups A and B with respect to the SRS30 questionnaire. Conclusions: Patients with idiopathic adolescent scoliosis submitted to arthrodesis of the lumbar curve have a better coronal alignment when the distal fusion level is L3. Level of evidence III; Comparative Retrospective Study (based on prospectively collected data).
\end{abstract}

Keywords: Scoliosis; Treatment Outcome; Quality of Life; Spinal Fusion.

\section{RESUMO}

Objetivo: Avaliar o alinhamento coronal em pacientes com escoliose idiopática do adolescente com curvas lombares estruturadas submetidos ao tratamento cirúrgico, realizando uma comparação entre o alinhamento coronal no grupo fusionado até L3 e o grupo fusionado até L4. Métodos: Estudo retrospectivo de coorte. Avaliados pacientes submetidos ao tratamento cirúrgico com artrodese da curva lombar com alta densidade de parafusos, com pelo menos 6 meses de seguimento. Radiograficamente, foram analisados: alinhamento coronal, altura dos ombros e resultado funcional através do questionário SRS30. Resultados: Um total de 25 pacientes foram analisados, sendo 23 do sexo feminino e 2 do sexo masculino, com idade média de 15,2 anos (12 a 29 anos) na data da cirurgia. Os pacientes foram subdivididos em dois grupos. Grupo A: nível distal de fusão em L3. Grupo B: nível distal de fusão em L4. O grupo A teve um n total de 15 pacientes e o grupo B um $n$ total de 10 pacientes. Não houve diferença estatisticamente significativa entre os grupos $A$ e $B$ quando comparados em relação ao alinhamento coronal (equilibrados x não-equilibrados). Entretanto, quando comparados em relação ao valor em milímetros do alinhamento coronal (AC), observou-se menores valores de AC no grupo A, com significância estatística. Não foi observada diferença entre os grupos A e B no que diz respeito ao questionário SRS30. Conclusões: Os pacientes com escoliose idiopática do adolescente, submetidos à artrodese da curva lombar, têm um melhor alinhamento coronal quando o nível distal de fusão é L3. Nível de evidência III; Estudo Retrospectivo Comparativo (baseado em dados colhidos prospectivamente).

Descritores: Escoliose; Resultado de Tratamento; Qualidade de Vida; Fusão Vertebral.

\section{RESUMEN}

Objetivo: Evaluar la alineación coronal en pacientes con escoliosis idiopática del adolescente con curvas lumbares estructuradas sometidos al tratamiento quirúrgico, haciendo una comparación entre la alineación coronal en el grupo con fusión hasta L3 y el grupo con fusión hasta L4. Métodos: Estudio retrospectivo de cohorte. Se evaluaron pacientes sometidos a tratamiento quirúrgico con artrodesis de curva lumbar con alta densidad de tornillos, con al menos 6 meses de seguimiento. Radiográficamente, se analizaron alineación coronal, altura de los hombros y resultado funcional mediante el cuestionario SRS30. Resultados: Un total de 25 pacientes fueron analizados, de los cuales 23 eran del sexo femenino y 2 del sexo masculino, con edad promedio de 15,2 años (12 a 29 años) en el momento de la cirugía. Los pacientes fueron divididos en dos grupos. Grupo A, $n=15$ : nivel distal de fusión en L3. Grupo B, $n=10$ : nivel distal de fusión en L4. No hubo diferencia estadísticamente significativa entre los grupos A y B en comparación con la alineación coronal (equilibrados x no 
equilibrados). Sin embargo, en comparación con los valores de alineación coronal (AC), se observaron valores de AC más bajos en el grupo A, con significación estadística. No se observó diferencia entre los grupos A y B con respecto al cuestionario SRS30. Conclusiones: Los pacientes con escoliosis idiopática del adolescente sometidos a artrodesis de la curva lumbar tienen mejor alineación coronal cuando el nivel distal de fusión es L3. Nivel de evidencia III, Estudio Retrospectivo Comparativo (basado en datos obtenidos prospectivamente).

Descriptores: Escoliosis; Resultado del Tratamiento; Calidad de Vida; Fusión Vertebral.

\section{INTRODUCTION}

The definition of the arthrodesis level is the most important individual factor in the postoperative outcome of corrective idiopathic scoliosis surgery. ${ }^{1}$ Historically, fusion criteria have been evolving over the years, accompanied by changes in spinal correction techniques and instrumentation. ${ }^{2}$

At the beginning of scoliosis surgery, during the period of correction with plaster, Risser proposed arthrodesis up to the vertebra parallel to the ground following the application of plaster. ${ }^{3}$ In the 1970s, at the beginning of vertebral instrumentation, Harrington proposed that arthrodesis should extend one level above the proximal Cobb and two levels below the distal Cobb, provided that it was in the stable zone (between the foramina of S1). ${ }^{4}$ Later, in the modern era of spine surgery, $\mathrm{Moe}^{5}$ established the neutral vertebra (NV) as the boundary of the arthrodesis and, subsequently in a retrospective study, King reported better results when the arthrodesis extended to the stable vertebra (SV). ${ }^{6}$

More recently, Lenke popularized the concept of the touched vertebra (TV) as the appropriate arthrodesis level for some curves. The term substantially touched vertebra (STV) was later defined as the first vertebra touched by the medial sacral line since touching the pedicle. ${ }^{7}$ At the same time, Suk proposed a classification that defines the distal level of the lumbar arthrodesis according to the rotation and translation of L3 in tilt radiographs, ${ }^{1}$ although there is no consensus around the ideal distal level.

All these criteria were established in order to decrease the number of arthrodesed levels, which is even more important when the arthrodesis extends to the lumbar curve. ${ }^{8,9}$ Although some studies report a higher index of lumbar pain and greater disc degeneration the more distal the arthrodesis, some studies report greater coronal imbalance with shorter arthrodeses. ${ }^{7,10-13}$

The objective of this study is to compare the clinical and radiographical results of patients submitted to posterior arthrodesis stopping at $L 3$ or $L 4$ and to compare the criteria established in the literature to define the distal arthrodesis level (Suk ${ }^{1}$ and stable vertebra) with those established by the author.

\section{METHODS}

This is a retrospective study based on prospectively collected data. Following approval by the local institutional review board (IRB - 82768218.9.0000.0023), the medical records and imaging examinations of patients submitted to surgical treatment for adolescent idiopathic scoliosis (AIS) in a single center, with at least 6 months of follow-up, were evaluated.

Patients who underwent posterior approach deformity correction with inclusion of the lumbar curve (below L2 with lumbar modifier $\mathrm{B}$ or $\mathrm{C}$ ) were included, that is, patients whose lumbar curves were considered structured and were included in the arthrodesis. Patients with no lumbar curve (lumbar modifier A) or for whom the lumbar curve was not included (selective thoracic arthrodesis) were excluded. Patients with other deformities (neuromuscular, congenital, and syndromic) and those who underwent anterior approach surgery were also excluded.

All patients were operated by the same surgeon in a single center using the same surgical correction technique with high density of screws and direct vertebral derotation (DVD). ${ }^{1,14}$

The patients with the distal level of the arthrodesis of the lumbar curve in L3 (GROUP L3) were compared with the patients with the distal level of the arthrodesis in L4 (GROUP L4). The criterion used was defined by the assisting physician, whose philosophy was to always stop as proximally as possible in the lumbar curve, trying to stop at L3 even if it was not touched by the medial sacral line (TV-1). The cases where the arthrodesis stopped at L4 were those with great apical vertebral translation (AVT) and with L4 being the TV-1 (Figure 1).

\section{Clinical and radiographical evaluation}

The clinical evaluation was conducted using the SRS 30 questionnaire (Scoliosis Research Society) in the preoperative period (PRE), at the first postoperative visit (IPO), and the last postoperative follow-up (LPO). These questionnaires are already regularly filled out by the patients and are included in their medical records.

The radiographical evaluation was conducted using the following parameters: Cobb angle of the proximal thoracic curve (CobbTp), Cobb of the principle thoracic curve (CobbTP), Cobb of the thoracolumbar/lumbar curve (CobbTL/L) in the standing and tilt radiographs. The AVT (apical vertebral translation) and AVR (apical vertebral rotation) of the thoracic curves (AVT T) and L/TL (AVT L), which denote, respectively, the translation and rotation of the apical vertebra, were defined. The coronal alignment (CA) (distance of the $\mathrm{C} 7$ plumb line to the medial sacral line [MSL] in $\mathrm{cm}$ ), the angulation of L4 (AL4) (angle of L4 in relation to the horizontal), and the height of the shoulders $(\mathrm{AO})$ (difference in height between the apices of the coracoid processes, in $\mathrm{cm}$ ) were measured. ${ }^{15-17}$ (Figures 2-4) The individuals analyzed were divided into balanced (B) and non-balanced (NB) in all the evaluations (PRE, IPO, and LPO), balanced individuals considered to be those with CA of up to $2 \mathrm{~cm}$. All measurements were taken by the same examiner using Surgimap Spine software (Nemaris Inc., New York, NY)

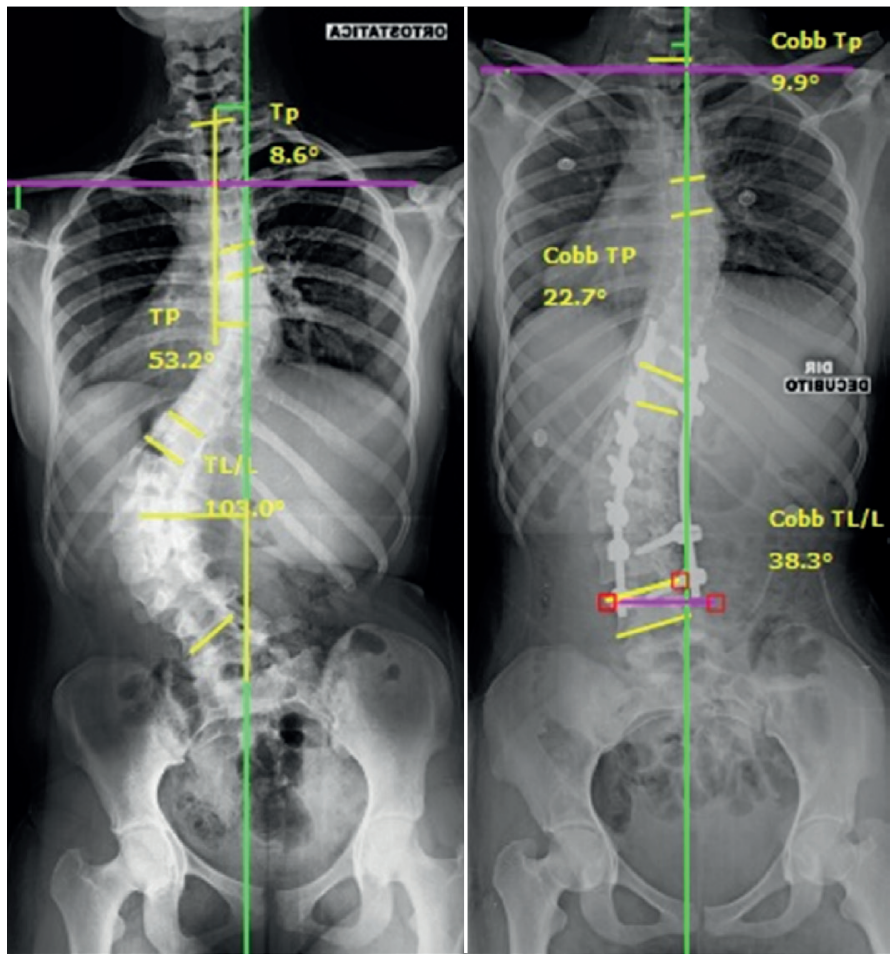

Figure 1. Example of patient submitted to arthrodesis down to L4. In this case, the touched vertebra (TV) is L5 and the TV-2 is L3. 


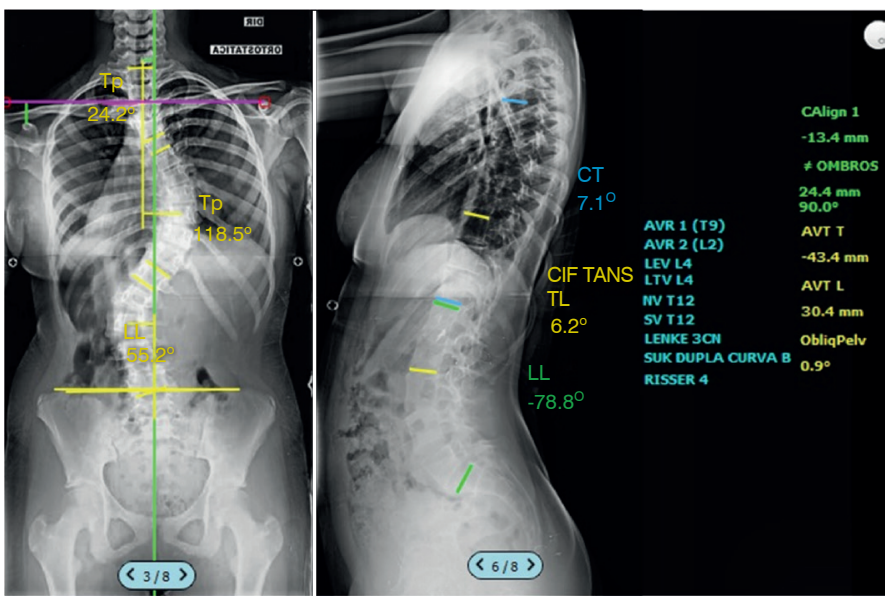

Figure 2. Radiographic criteria measured in preoperative orthostatic radiographs. CobbTp (proximal thoracic Cobb angle), CobbTP (principle thoracic Cobb angle), CobbTL/L (thoracolumbar/lumbar Cobb angle), AVT L (lumbar apical vertebral translation $-\mathrm{cm}$ ), $\mathrm{AO}$ (height of shoulders $-\mathrm{cm}$ ), and CA (coronal alignment).

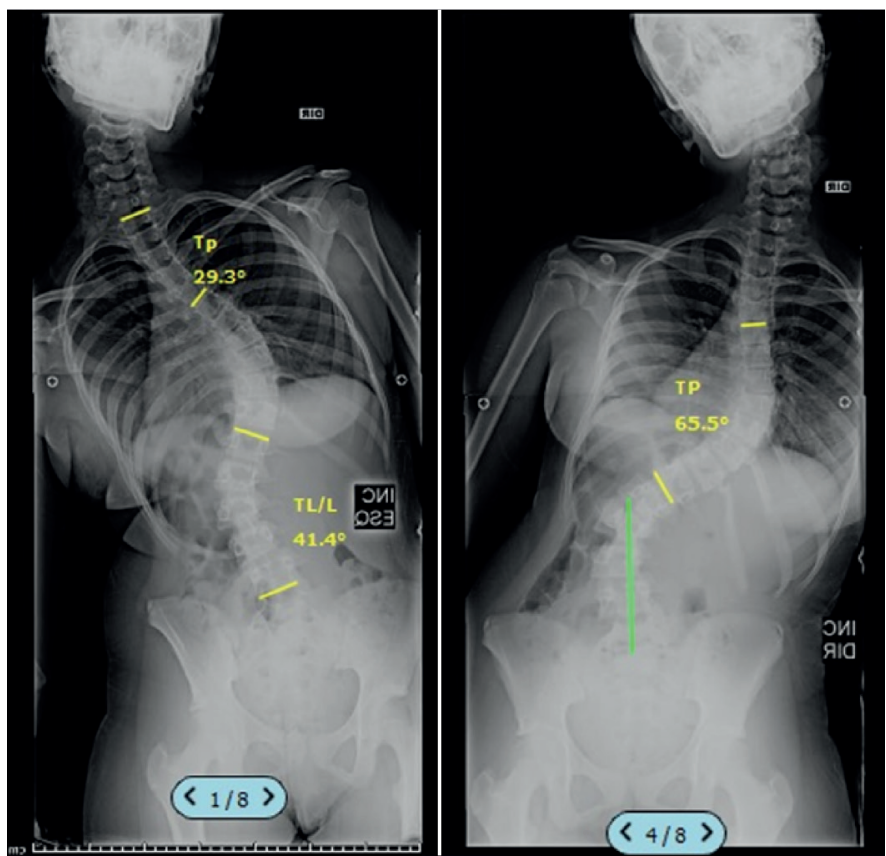

Figure 3. Radiographical criteria measured in tilt radiographs. CobbTp (Cobb proximal thoracic), CobbTP (Cobb principal thoracic), and Cobb TL/L (Cobb thoracolumbar/ lumbar).

All curves were classified according to Lenke ${ }^{17}$ and Suk ${ }^{1}$ and the fusion criteria of these authors were compared with the option chosen by the surgeon.

Criterion for distal fusion of the stable vertebra: stop at the vertebra bisected by the medial sacral line $(\mathrm{MSL}){ }^{6}$

Suk's criterion for distal fusion: stop at L3 when it exceeds the medial sacral line in the right lateral inclination and rotation is less than Nash-Moe 2 in the left lateral inclination. Otherwise, the fusion should be extended to L4.

Author's criterion for distal fusion: Always try to stop at L3, even if it is not touched at the medial sacral line (TV-1). Stop at L4 only when L3 is TV-2, i.e., L4 must be TV-1.

\section{Statistical analysis}

The entire statistical analysis was conducted using SPSS software (version 24.0, IBM SPSS, Inc.). All data were presented as means and medians, standard deviation, and confidence interval (95\%). Data distribution was tested by applying the Shapiro-Wilk test. For

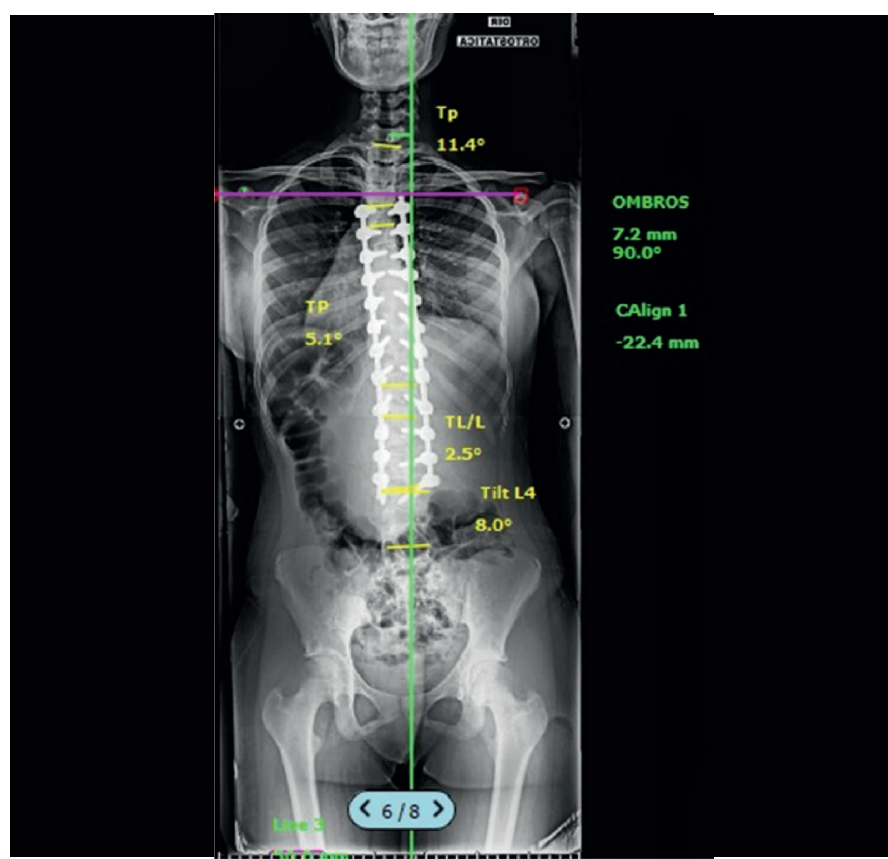

Figure 4. Radiographical criteria measured in postoperative orthostatic radiographs. CobbTp (Cobb proximal thoracic), CobbTP (Cobb principle thoracic), CobbTL/L (Cobb thoracolumbar/lumbar), AO (shoulder height - $\mathrm{cm}$ ), and CA (coronal alignment).

comparisons between means, when the distribution was identified as parametric, the Student's t-test for independent samples was used. When the data were non-parametric, the Mann-Whitney test was used. The categorical variables were presented by frequency as absolute numbers and ratios. The analysis of the distribution of the categorical variables was conducted by applying the Chi-square or Fisher's exact test (frequency less than five). We also used Cochran's $Q$ test for the comparison of ratios in related samples with more than two categories, Pearson's correlation analysis test, and Friedman's two-way analysis of variance by ranks in related samples. All tests were applied considering a significance level of $5 \%$ and a confidence interval of $95 \%$.

\section{RESULTS}

Twenty-five patients were evaluated, of whom 23 (92\%) were female and 2 (8\%) were male, with a mean age of 15.2 years (minimum of 12 years and maximum of 29 years). The mean follow-up time was 38.5 months (minimum of 10 and maximum of 67 ). According to the Lenke classification, ${ }^{11} 3$ (20\%) patients were type 1, 6 (24\%) were type 3 , (12\%) were type 4, 2 (8\%) were type 5, and 11 (44\%) were type 6. Twenty-four patients (96\%) presented lumbar modifier $\mathrm{C}$ and only 1 (4\%) lumbar modifier B. As regards the Suk classification, 13 patients (52\%) presented double major type curves, 11 (44\%) thoracolumbar and lumbar type curves, and 1 (4\%) a curve of the simple thoracic type.

In terms of the distal level of the arthrodesis, fusion extended to L3 (GROUP 3) in 15 (60\%) patients and to L4 (GROUP 4) in 10 (40\%) patients.

\section{Radiographical assessment}

The mean Cobb values in the PRE, IPO, and LPO are shown in Table 1. The percentage of correction of the TL/L curve in GROUP L3 was 62\% and in GROUP L4 was 66\%. There was no statistical difference between the groups.

As regards coronal alignment (CA), in the preoperative period (PRE) 15 patients (60\%) were non-balanced (NB), while 10 (40\%) were balanced (B) In the immediate postoperative period (IPO). The ratio did not get worse, but remained the same and improved over the long term, $15(60 \%)$ NB and 10 (40\%) B, however in the final assessment there 
was significant improvement of this parameter with 18 (78\%) B and 7 (28\%) NB ( $p=0.038$ according to Cochran's $Q$ test for related samples. When we evaluated the patients in GROUP L3 separately, there was a tendency towards improvement in the CA from PRE to LPO and in GROUP L4 a tendency towards worsening (Figure 5).

The CA was also evaluated quantitatively. There was a statistical difference in CA when the LPO measurements were compared between the two groups. (Table 2)

The values of AL4 are shown in Table 3. There was no statistical difference between the groups.

No difference was observed between the preoperative height of the shoulders and AVT measurements between the two groups. (Tables 4 and 5)

When the patients were divided by distal fusion level indicated, we observed the following: using the author's criteria, the last instrumented vertebra was $L 3$ in 15 patients (60\%) and $L 4$ in 10 patients $(40 \%)$ and using the criteria of Suk, ${ }^{1}$ of all the patients analyzed, only $10(40 \%)$ should stop at L3. When we evaluated the criterion of the stable vertebra, we observed that no patient should have the last vertebra instrumented in L3, with 2 patients (8\%) with fusion to L4 and 21 patients (92\%) to L5. (Table 6)

\section{Clinical Assessment}

Of the 25 patients included in the study, 12 answered the SRS30 quality of life questionnaire completely. After proper analysis, we observed that among these patients there was a statistically significant improvement in the appearance. There was no influence from the treatment on the remaining domains. (Table 7) There were no statistical differences between the groups in terms of the quality of life questionnaire parameters.

Table 1. Cobb values, Student's t-test.

\begin{tabular}{c|c|c|c}
\hline & Group L3 & Group L4 & \\
\hline COBBTp & Mean (SD) & Mean (SD) & Value of $\mathbf{p}^{*}$ \\
\hline PRE & $21.20(12.74)$ & $20.49(11.17)$ & 0.903 \\
\hline IPO & $17.50(13.0)$ & $17.89(10.40)$ & 0.937 \\
\hline LPO & $13.87(11.13)$ & $15.29(7.77)$ & 0.741 \\
\hline COBBTP & & & \\
\hline PRE & $53.97(16.87)$ & $65.25(27.01)$ & 0.210 \\
\hline IPO & $26.25(9.87)$ & $29.01(15.99)$ & 0.597 \\
\hline LPO & $27.57(11.25)$ & $27.09(13.20)$ & 0.926 \\
\hline COBBTL/L & & & \\
\hline PRE & $59.17(12.03)$ & $69.61(20.68)$ & 0.123 \\
\hline IPO & $19.81(11.52)$ & $24.95(15.90)$ & 0.357 \\
\hline LPO & $22.19(12.18)$ & $23.00(14.30)$ & 0.883 \\
\hline
\end{tabular}

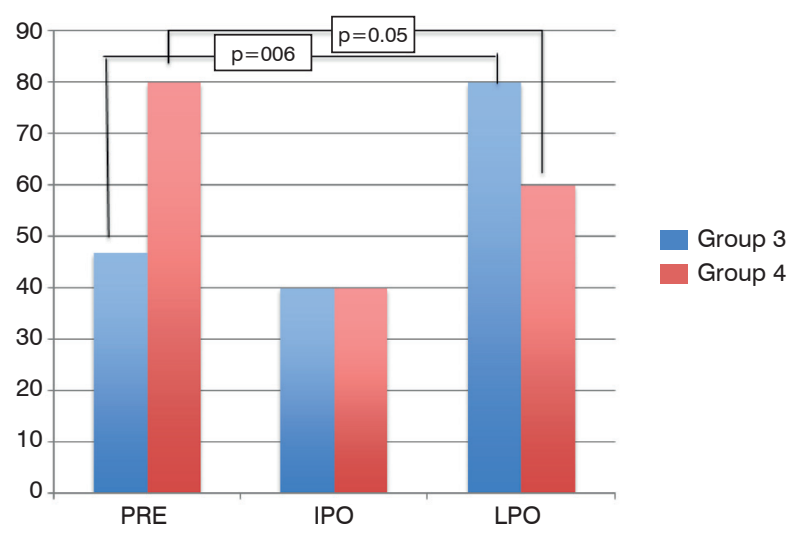

Figure 5. Percentage of Balanced patients in the two groups. In GROUP L3 there was a tendency towards improvement from the PRE to the LPO and in GROUP $L 4$ a tendency towards worsening.
Table 2. Coronal alignment values - measurements in $\mathrm{mm}$. Student's t-test.

\begin{tabular}{|c|c|c|c|}
\hline & Group L3 & Group L4 & \\
\hline & $\begin{array}{c}\text { Mean (SD) } \\
\text { Median (Cl 95\%) }\end{array}$ & $\begin{array}{c}\text { Mean (SD) } \\
\text { Median (CI 95\%) }\end{array}$ & Valor de $p$ \\
\hline PRE & $\begin{array}{c}23.27(12.23) \\
22.70(16.49-30.04)\end{array}$ & $\begin{array}{c}18.74(12.87) \\
15.70(9.53-27.95)\end{array}$ & 0.384 \\
\hline IPO & $\begin{array}{c}24.74(15.15) \\
23.40(16.35-33.13)\end{array}$ & $\begin{array}{c}28.19(15.89) \\
27.15(16.82-39.56)\end{array}$ & 0.590 \\
\hline LPO & $\begin{array}{c}12.31(8.32) \\
13.20(7.71-16.92)\end{array}$ & $\begin{array}{c}24.76(15.51) \\
18.10(12.83-36.68)\end{array}$ & 0.017 \\
\hline
\end{tabular}

Table 3. Values of the angle of $L 4$. Student's t-test.

\begin{tabular}{c|c|c|c}
\hline & Group L3 & Group L4 & \\
\hline TILT L4 & Mean (SD) & Mean (SD) & Valor de p \\
\hline Immediate Postop & $12.33(7.29)$ & $10.77(6.38)$ & 0.578 \\
\hline Late Postop & $11.54(7.34)$ & $11.02(6.62)$ & 0.856 \\
\hline
\end{tabular}

Table 4. Values of Height of Shoulders (AO) in mm. Student's t-test.

\begin{tabular}{c|c|c|c|c}
\hline $\begin{array}{c}\text { Height of the } \\
\text { Shoulders } \\
\text { (AO) }\end{array}$ & Group L3 & Group L4 & Value of & Total \\
\hline & Mean (SD) & Mean (SD) & p & Mean (SD) \\
\hline & $13.13(9.22)$ & $15.55(7.69)$ & 0.501 & $13.65(8.42)$ \\
\hline PRE & $12.97(9.89)$ & $13.86(11.92)$ & 0.841 & $12.16(8.94)$ \\
\hline IPO & $10.14(6.28)$ & $7.74(6.20)$ & 0.374 & $9.24(6.23)$ \\
\hline LPO & \multicolumn{4}{|c}{}
\end{tabular}

Table 5. Preoperative values of the translation and rotation of the apical vertebra. AVTL and AVTT in mm. AVT (apical vertebral translation) and AVR (apical vertebral rotation). Student's t-test.

\begin{tabular}{|c|c|c|c|}
\hline & Group L3 & Group L4 & \\
\hline & $\begin{array}{c}\text { Mean (SD) } \\
\text { Median (CI 95\%) }\end{array}$ & $\begin{array}{c}\text { Mean (SD) } \\
\text { Median (Cl 95\%) }\end{array}$ & Value of $p^{*}$ \\
\hline AVTL & $\begin{array}{c}44.42(16.74) \\
45.10(35.15-53.690\end{array}$ & $\begin{array}{c}51.14(20.20) \\
48.35(36.69-65.59)\end{array}$ & 0.374 \\
\hline AVTT & $\begin{array}{c}36.25(22.84) \\
30.00(23.61-48.90)\end{array}$ & $\begin{array}{c}37.81(24.64) \\
37.40(20.18-55.44)\end{array}$ & 0.873 \\
\hline AVRT & $\begin{array}{c}1.60(0.74) \\
2.00(1.19-2.01)\end{array}$ & $\begin{array}{c}1.50(0.85) \\
(0.89-2.11)\end{array}$ & 0.757 \\
\hline AVRL & $\begin{array}{c}2.40(0.83) \\
2.00(1.94-2.86)\end{array}$ & $\begin{array}{c}2.90(0.88) \\
3.00(2.27-3.53)\end{array}$ & 0.162 \\
\hline
\end{tabular}

Table 6. Distal level of arthrodesis according to the criteria of Suk, of the stable vertebra, and of the author.

\begin{tabular}{c|c|c|c}
\hline & L3 & L4 & L5 \\
\hline Criteria & $\mathbf{n}(\%)$ & $\mathbf{n}(\%)$ & $\mathbf{n}(\%)$ \\
\hline Suk & $10(40.0)$ & $15(60.0)$ & -- \\
\hline SV (stable vertebra) & --- & $2(8.0)$ & $23(92.0)$ \\
\hline Author's decision & $15(60.0)$ & $10(40.0)$ & -- \\
\hline
\end{tabular}

\section{DISCUSSION}

The objective of surgical treatment for AIS is to achieve a compensated trunk with the lowest number of arthrodesed vertebrae. ${ }^{18}$ This concept becomes even more important when the correction involves fusion of the lumbar curve. Some authors report a higher incidence of lumbar pain and disc degeneration in arthrodeses that extend distally to L3. ${ }^{19,20}$ Although more robust evidence of the correlation between extension of the arthrodesis and long-term functional results is still lacking in the literature, the choice of $L 3$ instead of $L 4$ during a fusion of the lumbar curve is the goal of most spine surgeons. ${ }^{18}$ However, the risk of decompensation and a lower angular correction can theoretically be increased with this type of approach.

This study showed that the patients submitted to arthrodesis up to L3 had improved CA, while the patients with arthrodesis up to $L 4$ had 
Table 7. Quality of life analysis according to the SRS-30 domains. The value of $p$ for Friedman's two-way analysis of variance by ranks in related samples.

\begin{tabular}{|c|c|c|c|c|}
\hline & PO & $\begin{array}{l}\text { Immediate } \\
\text { Postop }\end{array}$ & Late Postop & $\begin{array}{c}\text { Value of } \\
p^{*}\end{array}$ \\
\hline & Mean (SD) & Mean (SD) & Mean (SD) & \\
\hline Function $(n=12)$ & $3.38(0.77)$ & $3.49(0.64)$ & $3.58(0.72)$ & 0.937 \\
\hline Pain $(n=14)$ & $3.80(0.94)$ & $4.08(1.00)$ & $4.08(1.03)$ & 0.559 \\
\hline Appearance $(n=12)$ & $3.15(0.91)$ & $4.04(0.56)$ & $4.12(0.60)$ & 0.025 \\
\hline Mental Health $(n=12)$ & $3.48(0.92)$ & $3.93(0.85)$ & $3.72(0.84)$ & 0.146 \\
\hline Satisfaction $(n=12)$ & $3.93(0.97)$ & $4.48(0.55)$ & $4.61(0.60)$ & 0.146 \\
\hline SRS-30 total $(n=12)$ & $3.50(0.69)$ & $3.95(0.55)$ & $3.96(0.65)$ & 0.027 \\
\hline \multicolumn{5}{|c|}{ LIV L3 $(n=7)$} \\
\hline & Mean (SD) & Mean (SD) & Mean (SD) & \\
\hline Function & $3.37(0.40)$ & $3.46(0.76)$ & $3.78(0.75)$ & 0.867 \\
\hline Pain & $3.88(0.69)$ & $4.06(0.96)$ & $4.05(1.19)$ & 0.756 \\
\hline Appearance & $3.06(0.97)$ & $3.86(0.56)$ & $4.00(0.73)$ & 0.191 \\
\hline Mental Health & $3.54(1.09)$ & $3.88(0.94)$ & $3.55(0.56)$ & 0.341 \\
\hline Satisfaction & $4.00(1.29)$ & $4.43(0.50)$ & $4.52(0.77)$ & 0.878 \\
\hline SRS-30 total & $3.51(0.62)$ & $3.89(0.60)$ & $3.90(0.77)$ & 0.236 \\
\hline \multicolumn{5}{|c|}{ LIV L4 $(n=5)$} \\
\hline & Mean (SD) & Mean (SD) & Mean (SD) & \\
\hline Function & $3.40(1.17)$ & $3.51(0.73)$ & $3.45(0.90)$ & 0.946 \\
\hline Pain & $3.68(1.29)$ & $4.10(1.17)$ & $4.14(0.89)$ & 0.678 \\
\hline Appearance & $3.29(0.91)$ & $4.30(0.48)$ & $4.29(0.32)$ & 0.074 \\
\hline Mental Health & $3.40(0.73)$ & $4.00(0.80)$ & $3.96(1.15)$ & 0.247 \\
\hline Satisfaction & $3.83(0.24)$ & $4.57(0.66)$ & $4.73(0.28)$ & 0.056 \\
\hline SRS-30 total & $3.48(0.84)$ & $4.04(0.51)$ & $4.06(0.51)$ & 0.074 \\
\hline
\end{tabular}

a tendency towards worsening. This outcome may be associated with the presence of one more mobile segment distal to the arthrodesis that allows the trunk to be compensated. Another interesting factor was the worsening in the IPO and then improvement in the LPO in both groups, showing that an early radiographical assessment has little importance in relation to trunk balance. Lee also showed greater decompensation of the trunk in patients with arthrodesis to $L 4$ as compared to L3. However, in this study, in spite of the large case series, this difference was not statistically significant. ${ }^{21}$

In relation to the angular correction, there was no difference in the percentage of lumbar curve and AL4 correction. The same results were also reported by Lee, although he warned of a possibly lower correction when the last vertebra is $L 5{ }^{21}$

As regards the clinical results, the patients generally presented significant improvement in the domain of personal appearance and of the overall questionnaire. However, there was no difference when groups 3 and 4 were compared. The lack of a clinical difference in the short-term assessment of these two groups of patients is corroborated by other studies in the literature. ${ }^{18,21}$

When we evaluated the percentage of patients submitted to arthrodesis to $L 3$ in relation to the most popular criteria in the literature, we observed that the author's criteria permit shorter arthrodeses in a significant percentage of patients with similar clinical and radiographical results. This demonstrates that Suk's criteria and the stable vertebra criteria may be overestimating the need for arthrodesis to $L 4$.

This study has a series of limitations: first, for its retrospective design even though the data was collected prospectively; additionally, for the small case series and short follow-up time; finally, for the low proportion of patients who filled out the quality of life questionnaires correctly, impacting the clinical assessment of this group of patients.

\section{CONCLUSION}

Stopping arthrodesis in L3, which presents similar clinical and radiographical results in the short term, may be a good option in order to save levels in the lumbar region. It can be performed even in cases where the other criteria indicate arthrodesis up to $L 4$, such as when L 3 is the TV or even the TV-1.

All authors declare no potential conflict of interest related to this article.

CONTRIBUTION OF THE AUTHORS: Each author made significant individual contributions to this manuscript. MTD (0000-0001-9589-5596)* was the lead surgeon and developed the concept of the study. NCM (0000-0003-3879-6991)* helped with the writing of the manuscript. VNN (0000-0002-52808146)* and PFJ (0000-0003-3952-8470)* collected the data. BCRA (0000-0003-3875-8557)* is an instructor at the group's study center and worked on the bibliographical review. SD (0000-0003-0497-2010* is the senior doctor in the group and assisted with the concept and the manuscript. MFR (00000002-4050-5906)* worked on the final part of the manuscript and the review. ${ }^{*}$ ORCID (Open Researcher and Contributor ID).

\section{REFERENCES}

1. Suk SI. Pedicle screw instrumentation for adolescent idiopathic scoliosis: the insertion technique, the fusion levels and direct vertebral rotation. Clin Orthop Surg. 2011:3(2):89-100.

2. Badra MI, Feldman DS, Hart RA. Thoracic adolescent idiopathic scoliosis: selection of fusion level. J Pediatr Orthop B. 2010;19(5):465-72.

3. Risser JC. Scoliosis: past and present. J Bone Joint Surg Am. 1964;46:167-99.

4. Harrington PR. Technical details in relation to the successful use of instrumentation in scoliosis. Orthop Clin North Am. 1972;3(1):49-67.

5. Moe JH. Methods of correction and surgical techniques in scoliosis. Orthop Clin North Am. 1972:3(1):17-48

6. King HA. Selection of fusion levels for posterior instrumentation and fusion in idiopathic scoliosis. Orthop Clin North Am. 1988;19(2):247-55.

7. Qin X, Sun W, Xu L, Liu Z, Qiu Y, Zhu Z. Selecting the Last "Substantially" Touching Vertebra as Lowest Instrumented Vertebra in Lenke Type 1A Curve: Radiographic Outcomes With a Minimum of 2-year Follow-Up. Spine (Phila Pa 1976). 2016;41(12):E742-50.

8. Danielsson AJ, Cederlund CG, Ekholm S, Nachemson AL. The prevalence of disc aging and back pain after fusion extending into the lower lumbar spine. A matched MR study twenty-five years after surgery for adolescent idiopathic scoliosis. Acta Radiol. 2001;42(2):187-97.

9. Cochran T, Irstam L Nachemson A. Long-term anatomic and al changes in patients with adolescent idiopathic scoliosis treated by Harrington rod fusion. Spine (Phila Pa 1976). 1983;8(6):576-84.

10. Lee CS, HA JK, Kim DG, Kim H, Hwang CJ, Lee DH, et. al. The clinical importance of sacral slanting in patients with adolescent idiopathic scoliosis undergoing surgery. Spine J. 2015;15(5):834-40.

11. Bartie BJ, Lonstein JE, WInter RB. Long-Term follow-up of adolescent idiopathic scoliosis patients who had Harrington instrumental and fusion to the lower lumbar vertebra: is low back pain a problem? Spine (Phila Pa 1976). 2009;34(24):E873-8.

12. Danielsson AJ, Romberg K, Nachemson AL. Spinal range of motion, muscle endurance, and back pain and . at least 20 years after fusion or brace treatment for adolescente idiopathic scoliosis: a case-control study. Spine (Phila Pa 1976). 2006:31(3):275-83.

13. Danielsson AJ, Nachemson AL. Back pain and 23 years after fusion to adolescent idiopathic scoliosis: a case-control study-part II. Spine (Phila Pa 1976). 2003;28(18):E373-83.

14. Daher MT, Junior JHP, Nascimento VN, Melo NC, Netto LCM, Esperidião AP, et. al. Evaluation of cervical alignment and its relationship with thoracic kyphosis and spinopelvic parameters after scoliosis correction surgery. Coluna/Columna. 2017;16(4):265-9.

15. Dang NR, Moreau MJ, Hill DL, Mahood JK, Raso J. Intra-observer reproducibility and interobserver reliability of the radiographic parameters in the Spinal Deformity Study Group's AIS Radiographic Measurement Manual. Spine (Phila Pa 1976). 2005;30(9):1064-9.

16. Lenke LG, Betz RR, Bridwell KH, Clements DH, Harms J, Lowe TG, et al. Intraobserver and interobserver reliability of the classification of thoracic adolescent idiopathic scoliosis. J Bone Joint Surg Am. 1998;80(8):1097-106.

17. Lenke LG, Edwards CC, Bridwell KH. The Lenke classification of adolescent idiopathic scoliosis: how it organizes curve patterns as a template to perform selective fusions of the spine. Spine (Phila Pa 1976). 2003:28(20):S199-207

18. Ding R, Liang J, Qiu G, Shen J, Li Z. Evaluation of quality of life in adolescent idiopathic scoliosis with different distal fusion level: a comparison of L3 versus L4. J Spinal Disord Tech. 2014;27(5):E155-61.

19. Iharreborde B, Morel E, Mazda K, Dekutoski MB. Adjacent segment disease after instrumented fusion for idiopathic scoliosis: review of current trends and controversies. J Spinal Disord Tech. 2009;22(7):530-9.

20. Danielsson AJ, Nachemson AL. Back pain and. 23 years after fusion for adolescent idiopathic scoliosis: a case-control study-part II. Spine (Phila Pa 1976). 2003;28(18):E373-83.

21. Lee CS, Ha JK, Hwang CJ, Lee DH, Kim TH, Cho JH. Is it enough to stop distal fusion at L3 in adolescent idiopathic scoliosis with major thoracolumbar/lumbar curves? Eur Spine J. 2016;25(10):3256-64. 